\title{
Alkaloid Caulerpin and Cytotoxic Activity against NCL-H460 Lung Cancer Cells Isolated along with $\beta$-sitosterol from the Halimeda cylindracea Decaisne
}

(Alkaloid Kaulerpin dan Aktiviti Kesitotoksikannya terhadap Sel Barah Paru-Paru NCL-H460 Dipencilkan bersama $\beta$-sitosterol daripada Halimeda cylindracea Decaisne)

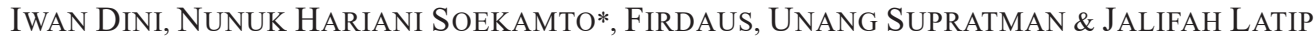

\begin{abstract}
Alkaloid caulerpin (1), along with $\beta$-sitosterol (2), were isolated from the n-hexane extract of the macroalga Halimeda cylindracea Decaisne. The chemical structure was identified by a spectroscopic method including IR, MS, UV, NMR ID, NMR 2D, and comparison with data of spectra previously reported. Compounds (1) and (2) were isolated for the first time from this macroalga. Compund (1) were evaluated for their cytotoxicity activity against NCL-H460 lung cancer cells in vitro and showed moderate activity with $I C_{50}$ value of $20.05 \mu \mathrm{g} / \mathrm{mL}$.
\end{abstract}

Keywords: $\beta$-sitosterol; caulerpin; Halimeda cylindracea; NCL-H460 lung cancer cells

\section{ABSTRAK}

Alkaloid kaulerpin (1), bersama dengan $\beta$-sitosterol (2), diasingkan daripada ekstrak n-heksana daripada makroalga Halimeda cylindracea Decaisne. Struktur kimia dikenal pasti dengan kaedah spektroskopi termasuk IR, MS, UV, NMR 1D, NMR 2D dan perbandingan dengan data spektrum yang dilaporkan sebelumnya. Sebatian (1) dan (2) diasingkan untuk pertama kalinya daripada makroalga ini. Sebatian (1) dinilai untuk aktiviti kesitotoksikannya terhadap sel barah paru-paru NCL-H460 secara in vitro dan menunjukkan aktiviti sederhana dengan nilai $I_{50} 20.05 \mu \mathrm{g} / \mathrm{mL}$.

Kata kunci: $\beta$-sitosterol; Halimeda cylindracea; kaulerpin; sel barah paru-paru NCL-H460

\section{INTRODUCTION}

Halimeda is one plant of macroalga genera which is the largest species, 48 species were reported, and is a genera of the family Halimedaceae (Guiry \& Guiry 2020). Species from this genus distributed in tropical and sub-tropical waters, mainly in the Indian Ocean, the Atlantic Ocean, and most in the Pacific Ocean (Hillis-Colinvaux 1980). There are 37 species from the Indo-Pacific Ocean and most is in the Indonesian Ocean (Kadi 1987). Halimeda is generally found in areas of high predator activity, so it too can produce a new segment that contains a high concentration of group chemical metabolite defense (Paul \& Fenical 1984; Paul \& Van Alstyne 1988).

The extracts of Halimeda show that it possesses diverse biological activity such as antiviral, antibacterial, and anticancer activity. $H$. tuna active to murine coronavirus strain A5Y, Gram-positive and Gramnegative bacterial and active to cancer cell HeLa, HepG2 and KB cell line (Indira et al. 2013; Koehn et al. 1991; Moo-Puc et al. 2009). H. opuntia active to bacterial such as Staphylococcus aureus, Pseudomonas aeruginosa, Enterococcus feacalis, and Escherichia coli (Selim 2012). H. incrassata active to cancer cell HeLa, HepG2 and KB cell line (Moo-Puc et al. 2009). H. macrolaba active to $S$. aureus, E. coli, and five vibrio strain (Govindasamy et al. 2011; Natrah et al. 2015). H. cylindracea active to $E$. coli, S. aureus, and Salmonella typhi (Dini et al. 2019). $H$. gracilis has potential as antioxidan, antibacterial, and larvisida activity (Suganya et al. 2019). 
The genus Halimeda produce alkaloid compounds (Guven et al. 2010; Ovenden et al. 2012; Su et al. 1998). In addition to compounds mentioned, most class from secondary metabolite reported from Halimeda are diterpenoid with acetate and aldehyde moiety such as halimedatetrasetat, halimedatrial, halitunal, udoteal, rhipocephalin, and rhipocephenal with antimicrobial and cytotoxic properties (Koehn et al. 1991; Paul \& Fenical 1984; Sun \& Fenical 1979; Tillekeratne \& Schmitz 1984). Steroid compounds that have been reported are cholesterol, $\Delta^{5}$-ergostenol, clionasterol, and $\beta$-sitosterol (Dzeha et al. 2003; Hendri et al. 2017; Patterson 1974). In the present study, we reported the isolation and structural determination, biological activity of alkaloid dimethyl-5,12-dihydrocycloocta[1,2- $\left.b: 5,6-b^{\prime}\right]$-diindole6,13-dicarboxylate (1), along with $\beta$-sitosterol from the H. cylindracea Decaisne that are collected from the gulf of Buni, South Sulawesi, Indonesia.

\section{MATERIALS AND METHODS}

\section{GENERAL EXPERIMENT PROCEDURES}

The IR spectra was measured on ZHIMADSU IR Prestige-21 in KBR. Massa spectra was obtained with a Shimadzu GCMS-QP2010 spectrometer. The UV spectra was measured on a Thermo Orion Aqua Mate 8000 UVVis spectrometer. The ${ }^{1} \mathrm{H}$ NMR and ${ }^{13} \mathrm{C}$ NMR APT spectra data was recorded with a BRUKER spectrometer (600 $\mathrm{MHz}$ for ${ }^{1} \mathrm{H}$ and $150 \mathrm{MHz}$ for ${ }^{13} \mathrm{C}$ ) using tetra methyl silane (TMS) as an internal standard. Chromatographic separation was carried out on silica gel 60 (Merck). TLC plates were precoated with silica gel $\mathrm{GF}_{254}$ (Merck, 0.25 $\mathrm{mm}$ ), detection was achieved with $10 \% \mathrm{CeSO}_{4}$ in $\mathrm{H}_{2} \mathrm{SO}_{4}$ $2 \mathrm{~N}$, followed by heating.

\section{PLANT MATERIAL}

H. cylindracea Decaisne was collected from the corral island in the Gulf of Boni, South Sulawesi, Indonesia ( $\left.4^{\circ} 03^{\prime} 19^{\prime} \mathrm{S}, 120^{\circ} 22^{\prime} 51^{\prime \prime} \mathrm{E}\right)$ in November 2018. The sample was collected in the morning and when seawater at the lowest ebb condition, from various depths $(0.5-2 \mathrm{~m})$. The sample macroalga was identified by Mrs. Tri Handayani, the staff of Research Center for Oceanography, LIPI Ancol, Indonesia, with identification number B7435/IPK.2/IF.07/XI/2019.

\section{EXTRACTION AND ISOLATION}

The dried sample of $H$. cylindracea Decaisne $(10.47 \mathrm{~kg})$ was extracted with $n$-hexane at room temperature for 4 days. After removal of the solvent trough evaporated in the reduce pressure, to give crude extracts $(12.87 \mathrm{~g})$. The $n$-hexane crude extract $(11.0 \mathrm{~g})$ was fractionated by column chromatography on silica gel 60 using a gradient $n$-hexane-EtOAc to give six fraction (A-F). Fraction D (830 mg) was fractionation by column chromatography on silica gel, eluted with a solvent of $n$-hexane:EtOAc (9:1) to give 75 fractions. Finally, fraction 33-40 (109 mg) was chromatographed on a column of silica gel, eluted with $n$-hexane:EtOAc $(8: 2)$ to give compound 1 (12.7 $\mathrm{mg})$. Fraction C (3.10 g) was chromatographed on a column silica gel, eluted with $n$-hexane-chloroform (8:2) to give seven fractions (C1-C7). White crude crystal on subfraction (C3) recrystallization with $n$-hexane and EtOAc to give compound 2 (462.0 mg).

Alkaloid caulerpin (1) - Compound 1 was obtained as solid red; mp. $318-320^{\circ} \mathrm{C}$; MS molecular peak at $\mathrm{m} / \mathrm{z}$ $398.40[\mathrm{M}]^{+}$; IR (KBr) $v_{\max } \mathrm{cm}^{-1}: 3381,3053,2951,2850$, 1687, 1625, 1560, 1265; UV absorption (nm) at 223, 277, 298, 314, and 365; ${ }^{1} \mathrm{H}-\mathrm{NMR}\left(\mathrm{CDCl}_{3}, 600 \mathrm{MHz}\right): \delta_{\mathrm{H}} 7.38$ $(1 \mathrm{H}, \mathrm{d}, J=8.4 \mathrm{~Hz}, \mathrm{H}-7), 7.45(1 \mathrm{H}, \mathrm{d}, J=7.8 \mathrm{~Hz}, \mathrm{H}-4)$, $7.05(1 \mathrm{H}, \mathrm{t}, J=7.2,7.8 \mathrm{~Hz}, \mathrm{H}-5), 7.13(1 \mathrm{H}, \mathrm{t}, J=7.8,7.8$ Hz, H-6), 8.21 (1H, s, H-9), 10.58 (1H, s, N-H), 3.80 ppm $\left(3 \mathrm{H}, \mathrm{s}, \mathrm{H}-\mathrm{OCH}_{3}\right) ;{ }^{13} \mathrm{C}-\mathrm{NMR}\left(\mathrm{CDCl}_{3}, 125 \mathrm{MHz}\right)$ : Table 1.

$\beta$-sitosterol (1) - Compound $\mathbf{2}$ was obtained as a needles white crystal; m.p. $132-134{ }^{\circ} \mathrm{C}$; MS molecular peak at $\mathrm{m} / \mathrm{z} 414.25[\mathrm{M}]^{+}$; IR $(\mathrm{KBr}) \mathrm{v}_{\max } \mathrm{cm}^{-1}: 3423,2935$, 2868, 1645, 1463, 1377, 1379, 1055; ${ }^{1} \mathrm{H}-\mathrm{NMR}\left(\mathrm{CDCl}_{3}, 600\right.$ MHz): $\delta_{\mathrm{H}} 5.34(1 \mathrm{H}$, brs, H-6), $3.51(1 \mathrm{H}, \mathrm{m}, \mathrm{H}-3), 0.68(3 \mathrm{H}$, s, H-18), 1.01 (3H, s, H-19), 0.93 (3H, d, H-21), 0.82 (3H, d, H-26), 0.85 (3H, d, H-27), 1.31 (3H, m, H-29); ${ }^{13} \mathrm{C}-\mathrm{NMR}$ $\left.\left(\mathrm{CDCl}_{3}, 125 \mathrm{MHz}\right)\right)$ : Table 2.

\section{CYTOTOXIC ASSAY}

The cytotoxic activities in $\mathrm{IC}_{50}$ (value is the concentration required for $50 \%$ growth inhibition) of compound 1 against NCL-H460 lung cancer cell was assessed using MTT assay. To do this process, NCL-H460 cell in an RPMI 1640 medium with a concentration of $1.5 \times 10^{4}$ cells were cultured in each 96-well plate with a volume of $100 \mu \mathrm{L}$. After $24 \mathrm{~h}$ incubation, the varying concentration of compound were added to the wells. The compounds added were first dissolved in DMSO at the required concentration. The sample concentration was prepared using PBS (phosphoric buffer solution, $\mathrm{pH}=7.30$ - 7.65), control wells received only DMSO. Cells were incubated at $37{ }^{\circ} \mathrm{C}$ with $5 \%$ carbon dioxide for $48 \mathrm{~h}$. Afterward, the cells were then examined for cytotoxic effects (cell 
rounding). In the next step, the wells were washed with $200 \mu \mathrm{L}$ of PBS and then $200 \mu \mathrm{L}$ of PBS and $25 \mu \mathrm{L}$ of MTT solution was added to the wells and incubated for $1 \mathrm{~h}$ at $37{ }^{\circ} \mathrm{C}$. Subsequently, optical absorption was recorded by ELISA reader at a wavelength of $595 \mathrm{~nm}$. The percentage of surviving cells was calculated and determined using the following formula. $\mathrm{IC}_{50}$ values were taken from the plotted graph of percentage live cells compared to control (\%), versus the tested concentration of compounds $(\mu \mathrm{g} / \mathrm{mL})$. Each assay and analysis was run in triplicate and averaged.
Percentage of surviving cells = Mean optical absorption of cells exposed to the sample solution / mean optical absorption of control cells $\times 100$.

\section{RESULTS AND DISCUSSION}

Alkaloid caulerpine $\mathbf{1}$ and $\beta$-sitosterol $\mathbf{2}$ was successively isolated from the $n$-hexane extract of $H$. cylindracea Decaisne for the first time. The molecule structure of compounds 1 and $\mathbf{2}$ (Figure 1) was determined using by IR, UV, MS, NMR spectroscopy measurements $\left({ }^{1} \mathrm{H}-\mathrm{NMR}\right.$, $\left.{ }^{13} \mathrm{C}-\mathrm{NMR}\right), 2 \mathrm{D}$ measurements $\left({ }^{1} \mathrm{H}-{ }^{1} \mathrm{H}\right.$ COSY, HSQC, HMBC, and NOESY), and compared data literature.
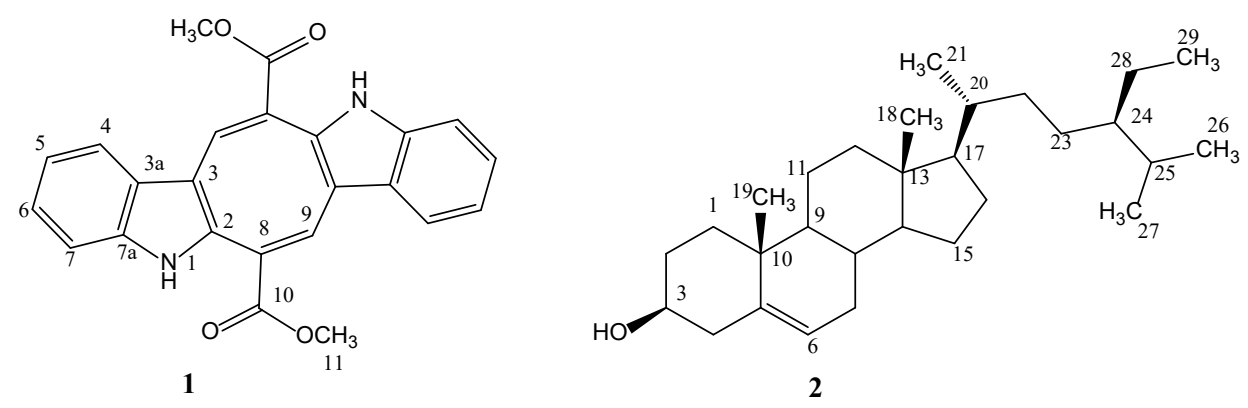

FIGURE 1. The structures of $\mathbf{1}$ and $\mathbf{2}$ from $H$. cylindracea Decaisne

Compound 1 was obtained as a solid red with melting point $318^{\circ} \mathrm{C}$. That can dissolve in dimethyl sulfoxide (DMSO) or acetone. Compound $\mathbf{1}$ have specific characteristic which is spot on the TLC is black phosphorescent under UV lamp (365 nm) and gives a red color after sprayed with $\mathrm{CeSO}_{4} 2 \%$ in sulfuric acid $2 \mathrm{~N}$.

The IR spectra data showed absorption $\left(\lambda_{\max } \mathrm{cm}^{-1}\right)$ to indicate a typical bonding of functional group N-H stretching (3381.21 cm-1), Ar-H stretching $\left(3053.32 \mathrm{~cm}^{-1}\right)$, $\mathrm{C}-\mathrm{H}$ aliphatic stretching $\left(2951.09 \mathrm{~cm}^{-1} \& 2850.79 \mathrm{~cm}^{-1}\right)$, $\mathrm{C}=\mathrm{O}$ stretching $\left(1687.71 \mathrm{~cm}^{-1}\right), \mathrm{C}=\mathrm{C}$ aromatic $(1560.41$ $\left.\mathrm{cm}^{-1} \& 1625 \mathrm{~cm}^{-1}\right)$, and $-\mathrm{CO}-\mathrm{O}$ ester $\left(1265.30 \mathrm{~cm}^{-1}\right)$. The MS show peak at $\mathrm{m} / \mathrm{z} 398.40$ corresponding to the molecule formula $\mathrm{C}_{24} \mathrm{H}_{18} \mathrm{O}_{4} \mathrm{~N}_{2}$, UV absorption at 277 and 298 indicated to indolic and $365 \mathrm{~nm}$ indolic conjugate with ester. In the UV and IR spectral analysis of $\mathbf{1}$ gave a typical spectra of alkaloid caulerpin (Maiti \& Thomson 1977). The ${ }^{1} \mathrm{H}-\mathrm{NMR}$ spectral data of compound 1 (Table 1 ), confirmed the presence of four signal of the aromatic proton with the multiplicities are two doublets at $\delta_{\mathrm{H}} 7.38$ ppm $(1 \mathrm{H}, \mathrm{d}, J=8.4 \mathrm{~Hz})$, and $7.45 \mathrm{ppm}(1 \mathrm{H}, \mathrm{d}, J=7.8$ $\mathrm{Hz})$ and two triplet at $\delta_{\mathrm{H}} 7.05 \mathrm{ppm}(1 \mathrm{H}, \mathrm{t}, J=7,2$ and 7.8 $\mathrm{Hz})$ and $7.13 \mathrm{ppm}(1 \mathrm{H}, \mathrm{t}, J=7.8$ and $7.8 \mathrm{~Hz})$, are signals were inferred the occurrence of the four aromatic carbon of indoles. The signals that appeared at $\delta_{H} 8.21 \mathrm{ppm}(1 \mathrm{H}$, s) were assigned to olefin proton with height frequency as an effect of the trans-crotonate $\beta$ proton carbonyl group (Lambert et al. 2018). Then, the presence of a typical signal for proton bonding on the nitrogen of indoles at $\delta_{\mathrm{H}}$ $10.58 \mathrm{ppm}(1 \mathrm{H}, \mathrm{s})$, and the last proton typical signal two of methoxy groups of ester at $\delta_{\mathrm{H}} 3.80 \mathrm{ppm}(6 \mathrm{H}, \mathrm{s})$. 
Based on the ${ }^{13} \mathrm{C}$ NMR (Table 1) with the Attached Proton Test (APT) and Multiple-Quantum Correlation (HMQC) experiment to a detailed analysis of compound 1 showed the presences of twelve carbon double signals consist of six quaternary carbon which signal resonances at $\delta_{\mathrm{C}} 132.31(\mathrm{C}-2), 111.27(\mathrm{C}-3), 127.06$ (C-3a), 137.39 (C-7a), 125.50 (C-8), and 165.27 (C=O10) $\mathrm{ppm}$, four resonances of $\mathrm{sp}^{2}$ methines aromatic carbon at $\delta_{\mathrm{C}} 117.08(\mathrm{C}-4), 119.46(\mathrm{C}-5), 122.12$ (C-6), and $110.94(\mathrm{C}-7) \mathrm{ppm}$, one $\mathrm{sp}^{2}$ methine carbon at $\delta_{\mathrm{C}}$ 141.24 (C-9) ppm, and one oxygenated methyl at $\delta_{\mathrm{C}}$ 50.95 (C-11) ppm. Then, the position of functional group and proton of compound $\mathbf{1}$ also detailed with Heteronuclear Multiple Bond Correlation (HMBC) and Correlated Spectroscopy $\left({ }^{1} \mathrm{H}-{ }^{1} \mathrm{H}\right.$ COSY) spectra (Figure 2), proton-proton correlations ortho-benzylic in $\mathrm{C}_{4}-\mathrm{C}_{5}-\mathrm{C}_{6}-\mathrm{C}_{7}$ supported HMBC correlation proton $(\mathrm{H}-4)$ to carbon $\left(\mathrm{C}_{3}\right.$, $\mathrm{C}_{6}$, and $\mathrm{C}_{7}$ ), proton ( $\left.\mathrm{H}-5\right)$ to carbon $\left(\mathrm{C}_{3}\right.$ and $\left.\mathrm{C}_{3 \mathrm{a}}\right)$, proton (H-6) to carbon $\left(\mathrm{C}_{4}\right.$ and $\mathrm{C}_{7 \mathrm{a}}$ ), and proton $(\mathrm{H} 7)$ to carbon $\left(\mathrm{C}_{3 \mathrm{a}}\right.$ and $\left.\mathrm{C}_{5}\right)$ showed the four proton of aromatic benzene ring from the indoles skeleton in compound 1 . Proton (H-9) correlation to carbon $\left(\mathrm{C}_{2}, \mathrm{C}_{3}, \mathrm{C}_{3 \mathrm{a}}, \mathrm{C}_{8}\right.$, and $\left.\mathrm{C}_{10}\right)$, and proton ( $\mathrm{H}-11)$ to carbon $\left(\mathrm{C}_{10}\right)$ is confirmed bisindole skeleton. All experiments of compound $\mathbf{1}$ and compared with the literature, such signals of compound $\mathbf{1}$ identical to alkaloid caulerpin spectroscopic data previously reported from green alga caulerpa (Alarif et al. 2010; Maiti \& Thomson 1977; Maiti et al. 1978).

Compound 2 ( $\beta$-sitosterol) was isolated as needles white crystal, with melting point of $132{ }^{\circ} \mathrm{C}$ and can dissolve in the chloroform. The compound did not give phosphorescent under the UV lamp, but gives a blue and to red color after sprayed with $\mathrm{CeSO}_{4} 2 \%$ in sulfuric acid $2 \mathrm{~N}$, the suggestion was support by positive result as the steroid compound. The MS show peak at $\mathrm{m} / \mathrm{z} 414.25$ corresponding to the molecule formula $\mathrm{C}_{29} \mathrm{H}_{50} \mathrm{O}$. The IR spectra data of 2 showed absorption $\left(\lambda_{\max } \mathrm{cm}^{-1}\right)$ aliphatic stretching $\left(2935.66 \mathrm{~cm}^{-1} \& 2868.15 \mathrm{~cm}^{-1}\right)$, aliphatic bending $-\mathrm{CH}_{2}\left(1463.97 \mathrm{~cm}^{-1}\right)$ and $-\mathrm{CH}_{3}\left(1377.17 \mathrm{~cm}^{-1}\right)$. The hydroxyl stretching absorption $\left(3423.65 \mathrm{~cm}^{-1}\right), \mathrm{C}-\mathrm{O}$ $\left(1055.06 \mathrm{~cm}^{-1}\right)$, and $\mathrm{C}=\mathrm{C}$ olefin $\left(1645.28 \mathrm{~cm}^{-1}\right)$. The IR spectrum of 2 representative the absorption frequencies of the $\beta$-sitosterol functional groups.

${ }^{1} \mathrm{H}-\mathrm{NMR}\left(\mathrm{CDCl}_{3} ; 600 \mathrm{MHz}\right)$ spectrum data at $\delta_{\mathrm{H}} 3.48$ ppm $(1 \mathrm{H}, m)$ showed the proton of $\mathrm{H}-3$, one proton at $\delta_{\mathrm{H}}$ $5.33 \mathrm{ppm}(1 \mathrm{H} . t)$ appeared the vinylic proton of $\mathrm{H}-6$ as the characteristic of methine from the $\beta$-sitosterol. The six proton signal at $\delta_{\mathrm{H}} 0.68(3 \mathrm{H}, s), 0.93(3 \mathrm{H}, d), 0.82(3 \mathrm{H}$, d), $0.85(3 \mathrm{H}, \mathrm{d})$, and $1.31(3 \mathrm{H}, d), 1.01(3 \mathrm{H}, \mathrm{s})$, showed the six methyl groups from the $\beta$-sitosterol skeleton. The ${ }^{13} \mathrm{C}$ NMR spectrum of compound 2 showed 29 signals. Signal at $\delta_{\mathrm{C}} 71.95 \mathrm{ppm}$ are the characteristic signal of carbon connected to oxygen of C-3, two signal at $\delta_{C}$ 121.85 and 141.00 are signal for carbon $\mathrm{sp}^{2}$ from $\mathrm{C}-5$ and C-6 double bounds. There is signal characteristic of the $\beta$-sitosterol. Based the on the ${ }^{13} \mathrm{C}$ NMR with the Attached Proton Test (APT) spectrum, compound $\mathbf{2}$ showed signal at $\delta_{\mathrm{C}} 12.06,19.58,19.06,19.23,19.80$, and 12.50 ppm for six methyls carbon, signal at $\delta_{\mathrm{C}} 141.00,36.72$, and $42.55 \mathrm{ppm}$ for three quaternary carbon, signal at $\delta_{c}$ $71.95,121.85,32.15,50.41,57.00,56.32,36.48,46.32$, and $29.25 \mathrm{ppm}$ for nine methylene carbon, and signal at $\delta_{\mathrm{C}} 37.51,31.86,42.51,32.13,21.23,40.03,24.51,26.71$, $34.18,28.43$, and $23.29 \mathrm{ppm}$ for eleven methines carbon. All of spectral data from compound 2 show similarity the absorption frequencies for $\beta$-sitosterol previously reported from $H$. graccilis (Henri et al. 2017).

TABLE $1 .{ }^{1} \mathrm{H}$ and ${ }^{13} \mathrm{C}$ NMR $\left({ }^{1} \mathrm{H}, 600 \mathrm{MHz},{ }^{13} \mathrm{C}, 125 \mathrm{MHz}\right.$ in acetone) Data for Compound $\mathbf{1}^{\mathrm{a}}$, and Caulerpin ${ }^{\mathrm{b}}\left({ }^{1} \mathrm{H}, 600\right.$ $\mathrm{MHz},{ }^{13} \mathrm{C}, 600 \mathrm{MHz}$ in $\mathrm{CDCl}_{3}$ ) (Alarif et al. 2010)

\begin{tabular}{|c|c|c|c|c|}
\hline $\begin{array}{l}\text { Carbon } \\
\text { position }\end{array}$ & $\delta_{\mathrm{C}}(\mathrm{ppm})^{\mathrm{a}} \Sigma \mathrm{C}$ & $\delta_{\mathrm{C}}(\mathrm{ppm})^{\mathrm{b}} \Sigma \mathrm{C}$ & $\begin{array}{c}\delta_{\mathrm{H}}(\mathrm{ppm}, \Sigma \mathrm{H}, \\
{\text { multiplicities })^{\mathrm{a}}}^{2}\end{array}$ & $\delta_{\mathrm{H}}(\mathrm{ppm}, \Sigma \mathrm{H}, \text { multiplicities })^{\mathrm{b}}$ \\
\hline 1 & & & $10.58(2 \mathrm{H}, \mathrm{brs})$ & $9.2(2 H, 2 \mathrm{NH})$ \\
\hline 2 & $132.31(2 C)$ & $132.8(2 C)$ & & \\
\hline 3 & $111.27(2 C)$ & $112.6(2 C)$ & & \\
\hline $3 a$ & $127.06(2 C)$ & $128.1(2 C)$ & & \\
\hline 4 & $117.08(2 C)$ & $118.0(2 C)$ & $7.45(2 H, d)$ & $7.0-7.4(8 H, A r)$ \\
\hline 5 & $119.46(2 C)$ & $120.7(2 C)$ & $7.05(2 \mathrm{H}, \mathrm{t})$ & \\
\hline 6 & $122.12(2 C)$ & $123.4(2 C)$ & $7.13(2 \mathrm{H}, \mathrm{t})$ & \\
\hline 7 & $110.94(2 C)$ & $111.5(2 C)$ & $7.38(2 \mathrm{H}, \mathrm{d})$ & \\
\hline $7 \mathrm{a}$ & $137.39(2 C)$ & $137.7(2 C)$ & & \\
\hline 8 & $125.50(2 C)$ & $125.1(2 C)$ & & \\
\hline 9 & $141.24(2 C)$ & $142.7(2 C)$ & $8.21(2 \mathrm{H}, \mathrm{s})$ & $8.1(2 \mathrm{H},=\mathrm{CH}-)$ \\
\hline 10 & $165.27(2 C)$ & $166.6(2 C)$ & & \\
\hline 11 & $50.92(2 C)$ & $52.3(2 C)$ & $3.80(6 H, \mathrm{~s})$ & $3.8\left(6 \mathrm{H}, 2 \mathrm{CO}_{2} \mathrm{Me}\right)$ \\
\hline
\end{tabular}



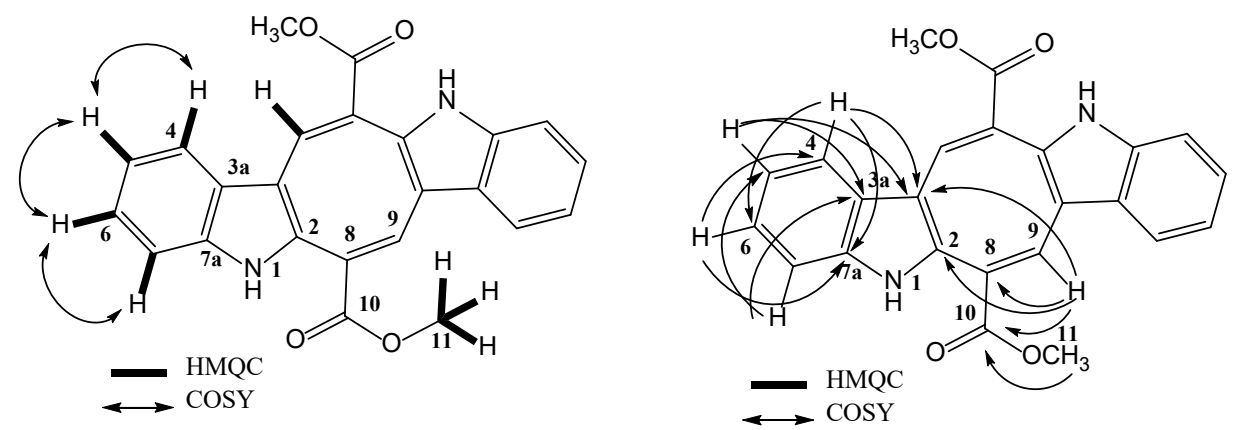

FIGURE 2. HMQC, COSY, and HMBC correlation of $\mathbf{1}$

In this study, Compound $\mathbf{1}$ cytotoxicity were evaluated against NCL-H460 lung cancer cell with $\mathrm{IC}_{50}$ value $20.05 \mu \mathrm{g} / \mathrm{mL}$ with positive control cisplatin $\mathrm{IC}_{50}$ $5.59 \mu \mathrm{g} / \mathrm{mL}$. The cytotoxicity effects of compound 1 has been reported as protein-tyrosine phosphatase 1B (PTP1B) inhibitory activity with $\mathrm{IC}_{50}$ values $5.86 \mu \mathrm{M}$ (Yang et al. 2014), active to several human cancers cell line; breast cancer SK-BR-3, lung cancer A549, colon cancer HT29, cervical cancer HeLa, leukemia K562, and liver cancer Huh7 with $\mathrm{IC}_{50}$ cytotoxicity values of 3.71 , $4.20,4.04,1.95,4.67$ and $0.72 \mu \mathrm{M}$, respectively (Li et al. 2018), anti-proliferation to cancer cell HCT-116 and HT-29 (Yu et al. 2017), have potential as antiviral against virus HSV-1, CHIKV line cell, and active to bovine viral diarrhea virus with $\mathrm{EC}_{50} 2.0 \mu \mathrm{M}$ (Esteves et al. 2019; Macedo et al. 2012; Pinto et al. 2012), inhibited the growth Mycobacterium tuberculosis cell strain $\mathrm{H} 37 \mathrm{Rv}$ with $\mathrm{IC}_{50}$ $0.24 \mu \mathrm{M}$ (Canche Chay et al. 2014).

TABLE 2. ${ }^{1} \mathrm{H}$ and ${ }^{13} \mathrm{C}$ NMR $\left({ }^{1} \mathrm{H}, 600 \mathrm{MHz},{ }^{13} \mathrm{C}, 125 \mathrm{MHz}\right.$ in $\mathrm{CHCl}_{3}$ ) data for Compound $2^{\mathrm{a}}$, and $\beta$-sitosterol ${ }^{\mathrm{b}}$ (Henri et al. 2017)

\begin{tabular}{|c|c|c|c|c|}
\hline $\begin{array}{l}\text { Carbon } \\
\text { position }\end{array}$ & $\delta_{\mathrm{C}}(\mathrm{ppm})$ & $\begin{array}{c}\delta_{\mathrm{H}}(\mathrm{ppm}, \Sigma \mathrm{H}, \\
\text { multiplicities })^{\mathrm{a}}\end{array}$ & $\delta_{\mathrm{C}}(\mathrm{ppm})$ & $\begin{array}{c}\delta_{\mathrm{H}}(\mathrm{ppm}, \Sigma \mathrm{H}, \\
\text { multiplicities })^{\mathrm{b}}\end{array}$ \\
\hline 1 & 37.51 & & 37.4 & \\
\hline 2 & 31.86 & & 31.8 & \\
\hline 3 & 71.95 & $3.51(1 \mathrm{H}, \mathrm{m})$ & 71.9 & $3.51(1 \mathrm{H}, \mathrm{m})$ \\
\hline 4 & 42.51 & & 42.4 & \\
\hline 5 & 141.00 & & 140.9 & \\
\hline 6 & 121.85 & $5.34(1 \mathrm{H}, \mathrm{t})$, & 121,9 & $5.34(1 \mathrm{H}, \mathrm{t})$ \\
\hline 7 & 32.13 & & 32.0 & \\
\hline 8 & 32.15 & & 32.1 & \\
\hline 9 & 50.41 & & 50.3 & \\
\hline 10 & 36.72 & & 36.7 & \\
\hline 11 & 21.31 & & 21.3 & \\
\hline 12 & 40.03 & & 39.9 & \\
\hline 13 & 42.55 & & 42.5 & \\
\hline 14 & 57.00 & & 56.9 & \\
\hline 15 & 24.51 & & 24.5 & \\
\hline 16 & 26.71 & & 26.5 & \\
\hline 17 & 56.32 & & 56.2 & \\
\hline 18 & 12.06 & $0.68(3 \mathrm{H}, \mathrm{s})$ & 12.0 & $0.67(3 \mathrm{H}, \mathrm{s})$ \\
\hline 19 & 19.58 & $1.01(3 \mathrm{H} . \mathrm{s})$ & 19.6 & $1.00(3 \mathrm{H}, \mathrm{s})$ \\
\hline 20 & 36.48 & & 36.4 & \\
\hline 21 & 19.06 & $0.83(3 \mathrm{H}, \mathrm{d})$ & 19.2 & $0.81(3 \mathrm{H}, \mathrm{d})$ \\
\hline 22 & 34.18 & & 34.1 & \\
\hline 23 & 28.43 & & 28.4 & \\
\hline 24 & 46.32 & & 46.2 & \\
\hline 25 & 29.25 & & 29.1 & \\
\hline 26 & 19.23 & $0.82(3 \mathrm{H}, \mathrm{d})$ & 19.0 & $0.82(3 \mathrm{H} \mathrm{d})$ \\
\hline 27 & 19.80 & $0.85(3 \mathrm{H}, \mathrm{d})$ & 19.8 & $0.84(3 \mathrm{H} \mathrm{d})$ \\
\hline 28 & 23.29 & & 23.2 & \\
\hline 29 & 12.50 & $1.31(3 \mathrm{H}, \mathrm{m})$ & 12.5 & $1.33(3 \mathrm{H}, \mathrm{m})$ \\
\hline
\end{tabular}




\section{CONCLUSION}

Alkaloid dimethyl-5.12-dihydrocycloocta-[1,2$\left.b: 5,6-b^{\prime}\right]$-diindole-6,13-dicarboxylate (1) and steroid compound, $\beta$-sitosterol (2) have been isolated for the first time from the H. cylindracea Decaisne. Compound 1 showed moderate activity against NCL-H460 lung cancer cells with $\mathrm{IC}_{50}$ value $20.05 \mu \mathrm{g} / \mathrm{mL}$. The result showed that a macroalga $H$. cylindracea Decaisne from the Gulf of Boni produce alkaloid and steroid compound.

\section{ACKNOWLEDGEMENTS}

This research was financially supported by Directorate General of Higher Education, Ministry of Education and Culture, Indonesia (BPP-DN scholarship and the doctoral grant 2019-2020). We thank Ms. Tri Handayani (the staff of Research Center for Oceanography, LIPI Ancol, Indonesia) for identification of the plant material. We would also like to thank Fitriani J. Sami for cytotoxic evaluation.

\section{REFERENCES}

Alarif, W.M., Abou-Elnaga, Z.S., Ayyad, S.E.N. \& Al-Lihaibi, S.S. 2010. Insecticidal metabolites from the green alga Caulerpa racemosa. CLEAN - Soil, Air, water 38(5-6): 548-557.

Canche Chay, C.I., Gómez Cansino, R., Espitia Pinzón, C.I., Torres-Ochoa, R.O. \& Martínez, R. 2014. Synthesis and antituberculosis activity of the marine natural product caulerpin and its analogues. Mar. Drugs. 12(4): 1757-1772.

Dini, I., Soekamto, N.H., Firdaus \& Supratman, U. 2019. Antibacterial and cytotoxic activities assay from the extract of macroalga Halimeda cylindracea from ulf of Boni, Indonesia. Journal of Physics: Conference Series 1341: 032035 .

Dzeha, T., Jaspars, M. \& Tabudravu, J. 2003. Clionasterol, a triterpenoid from the kenyan marine green macroalga Halimeda macroloba. Western Indian Ocean J. Mar. Sci. 2(2): 157-161.

Esteves, P.O., de Oliveira, M.C., de Souza Barros, C., CirneSantos, C.C., Laneuvlille, V.T. \& Palmer Paixão, I.C. 2019. Antiviral effect of caulerpin against chikungunya. Natural Product Communications 14(10): 1-6.

Guiry, M.D. \& Guiry, G.M. 2020. AlgaeBase. World-wide electronic publication, National University of Ireland, Galway. http://www.algaebase.org. Accessed on 07 September 2020.

Govindasamy, C.S., Narayani, M., Arulpriya, P., Ruban, K., Anantharaj \& Srinivasan, R. 2011. In vitro antimicrobial activities of seaweed extracts against human pathogens. Journal of Pharmacy Research 4(7): 2076-2077.

Güven, K.C., Percot, A. \& Sezik, E. 2010. Alkaloids in marine algae. J. Mar. Drugs 8(2): 269-284
Hendri, M., Darmanto, J.S., Prayitno, B., Radjasa, O.K. \& Elvita. 2017. The isolation of metabolite compounds from seaweed (Halimeda gracillis) in the waters of Teluk Lampung as a source of antibacterial compounds. International Journal of Marine Science 7(31): 297-307.

Hillis-Colinvaux, L. 1980. Ecology and taxonomy of Halimeda: Primary producer of coral reefs. Advances in Marine Biology 17: 1-327.

Indira, K.S., Balakrishnan, M., Srinivasan, S., Bragadeeswaran \& Balasubramanian, T. 2013. Evaluation of in vitro antimicrobial property of seaweed (Halimeda tuna) from Tuticorin coast, Tamil Nadu, Southeast coast of India. African Journal of Biotechnology 12(3): 284-289.

Kadi, A. 1987. Cara mengenal jenis-jenis dari marga Halimeda. Oseana XII(1): 1-12.

Koehn, F.E., Sarath, F., Gunasekera, D., Niel, N. \& Cross, S.S. 1991. Halitunal, an unusual diterpene aldehyde from the marine alga Halmeda tuna. Tetrahedron Letters 32(2): 169-172.

Lambert, J.B., Mazzola, E.P. \& Ridge, C.D. 2018. Nuclear Magnetic Resonance Spectroscopy: An Introduction to Principles, Applications, and Experimental Methods. 2nd ed. New York: John Wiley \& Sons.

Li, H., Liao, X., Sun, Y., Zhou, R., Long, W., Li, L., Gu, L. \& $\mathrm{Xu}, \mathrm{S} .2018$. An economical synthesis of Caulerpin and evaluation of its new anticancer activities. Chemistry Select 3: $12406-12409$.

Macedo, N.R.P.V., Ribeiro, M.S., Villaça, R.C., Ferreira, W., Pinto, A.M., Teixeira, V.L., Cirne-Santos, C., Paixao, I.C.N.P. \& Giongo, V. 2012. Caulerpin as a potential antiviral drug against herpes simplex virus type 1. Revista Brasileira de Farmacognosia 22: 861-867.

Maiti, B.C. \& Thomson, R.H. 1977. Caulerpin. In Marine Natural Products Chemistry, edited by Faulkner, D.J. \& Fenical, W.H. Nato Conference Series, Vol. 1. Boston, MA: Springer.

Maiti, B.C., Thomson, R.H. \& Mahendran, M. 1978. The structure of Caulerpin, a pigment from Caulerpa algae. J. Chem. Res. Synop. 9: 126-127.

Moo-Puc, R., Robledo, D. \& Freile-Pelegrin, Y. 2009. Actividad citotoxica y antiproliferativa in vitro de macroalgas marinas de Yucatan, Mexico. Ciencias Marina 35(4): $345-$ 358.

Natrah, F.M.I., Harah, Z.M., Sidik, B.J., Izzatul, N.M.S. \& Syahidah, A. 2015. Antibacterial activities of selected seaweed and seagrass from Port Dickson coastal water against different aquaculture pathogens. Sains Malaysiana 44(9): 1269-1273.

Ovenden, S.P.B., Nielson, J.L., Liptrot, C.H., Willis, R.H., Tapiolas, D.M., Wright, A.D. \& Motti, C.S. 2012. Update of spectroscopic data for 4-hydroxydictyolactone and dictyol E isolated from a Halimeda stuposa Dictyota $\mathrm{sp}$. Assemblage. Molecules 17(3): 2929-2938.

Patterson, G.W. 1974. Sterols of some green algae. Comparative Biochemistry and Physiology Part B 47(2): 453-457. 
Paul, V.J. \& Van Alstyne, K.L. 1988. Use of ingested algal diterpenoids by Elysia halimedae Macnae (Opisthobranchia: Ascoglossa) as antipredator defenses. Exp. Mar. Biol. Ecol. 119: 15-29.

Paul, V.J. \& Fenical, W. 1984. Novel bioactive diterpenoid metabolites from tropical marine algae of the genera halimeda (Chlorophyta). Tetrahedron 40(16): 3053-3062.

Pinto, A.M.V., Leite, J.P.G., Ferreira, W.J., Cavalcanti, D.N., Villaça, R.C., Giongo, V. \& de Palmer Paixão, I.C.N. 2012. Marine natural seaweed products as potential antiviral drugs against Bovine viral diarrhea virus. Revista Brasileira de Farmacognosia 22: 813-817.

Selim, S.A. 2012. Antimicrobial, antiplasmid and cytotoxicity potentials of marine algae Halimeda opuntia and Sarconema filiforme collected from Red Sea Coast. World Academy of Science, Engineering and Technology 6(1): 1154-1159S.

Su, J.Y., Xu, X.H., Zeng, L.M., Wang, M.Y., Lu, N., Lu, Y. \& Zhang, Q.T. 1998. Sym-triazine derivative from Halimeda xishaensis. Phytochemistry 48(3): 583-584.

Suganya, S., Ishwarya, R., Jayakumar, R., Govindarajan, M., Alharbi, N.S., Kadaikunnan, S., Khaled, J.M., Alanbr, M.N. \& Vaseeharan, B. 2019. New insecticides and antimicrobials derived from Sargassum wightii and Halimeda gracillis seaweeds: Toxicity against mosquito vectors and antibiofilm activity against microbial pathogens. South African Journal of Botany 125: 466-480.

Sun, H.H. \& Fenical, W. 1979. Rhipccephalin and rhipocephenal; toxic feeding deterrents from the tropical marine alga rhipccephaius phoenix. Tetrahedron Letters 8: 685-688.

Tillekeratne, L.M.V. \& Schmitz. F.J. 1984. 4,9-diaacetoxyyodoteal: A linear diterpene aldehyde from the green alga Halieda opuntia. Phytochemistry 23(6): 1331-1333.

Yang, H., Liu, D.Q., Liang, T.J., Li, J., Liu, A.H., Yang, P. \& Wang, B. 2014. Racemosin C, a novel minor bisindole alkaloid with protein tyrosine phosphatase-1B inhibitory activity from the green alga Caulerpa racemosa. Journal of Asian Natural Products Research 16(12): 1158-1165.
Yu, H., Zhang, H., Dong, M., Wu, Z., Shen, Z., Xie, Y., Kong, Z., Dai, X. \& Xu, B. 2017. Metabolic reprogramming and AMPK $\alpha 1$ pathway activation by Caulerpin in colorectal cancer cells. Int. J. Oncol. 50(1): 161-172.

Iwan Dini

Department of Chemistry

Faculty of Mathematics and Natural Sciences

Universitas Negeri Makassar, Makassar

Indonesia

Nunuk Hariani Soekamto* \& Firdaus

Department of Chemistry

Faculty of Mathematics and Natural Sciences

Universitas Hasanuddin, Makassar

Indonesia

Unang Supratman

Department of Chemistry

Faculty of Mathematics and Natural Sciences

Universitas Padjadjaran, Jatinangor

Indonesia

Unang Supratman

Central Laboratory of Universitas Padjadjaran

Jatinangor

Indonesia

Jalifah Latip

School of Chemical Science and Food Technology

Faculty of Science and Tecnology

Universiti Kebangsaan Malaysia

43600 UKM Bangi, Selangor Darul Ehsan

Malaysia

*Corresponding author; email: nunukhariani@unhas.ac.id

Received: 5 May 2020

Accepted: 19 January 2021 

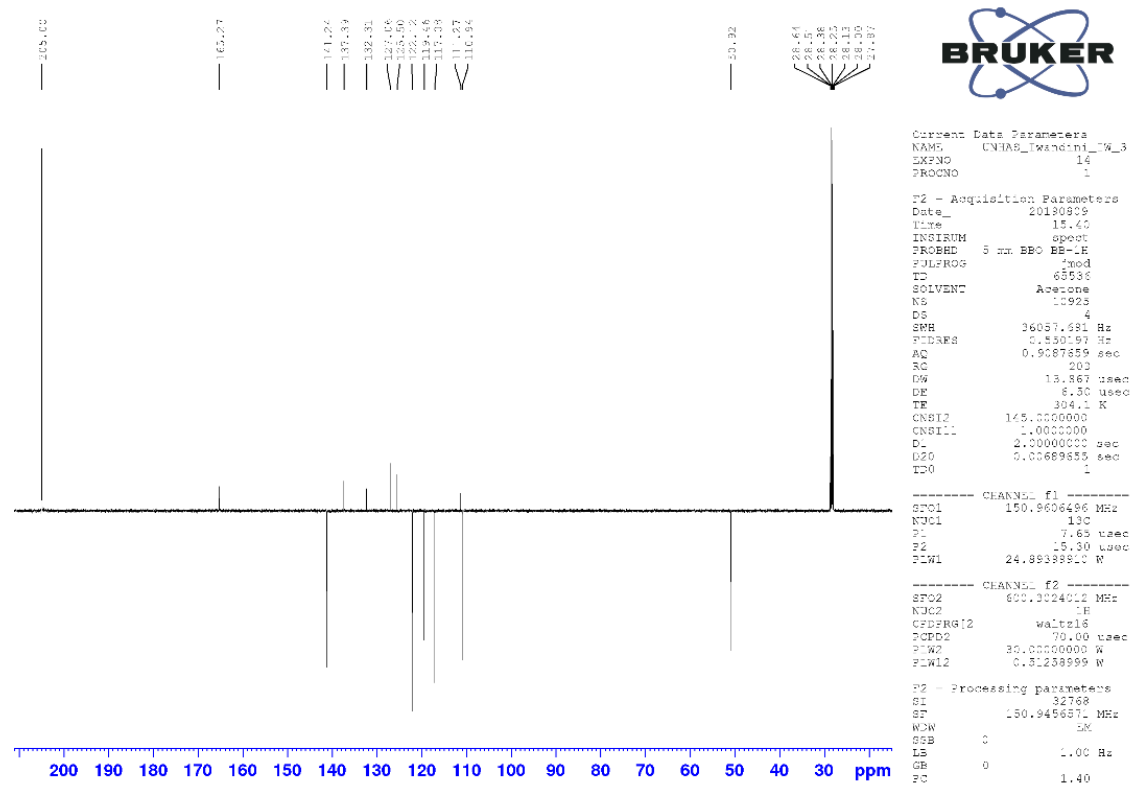

${ }^{13} \mathrm{C}$ NMR apt spectra of Compound $\mathbf{1}$

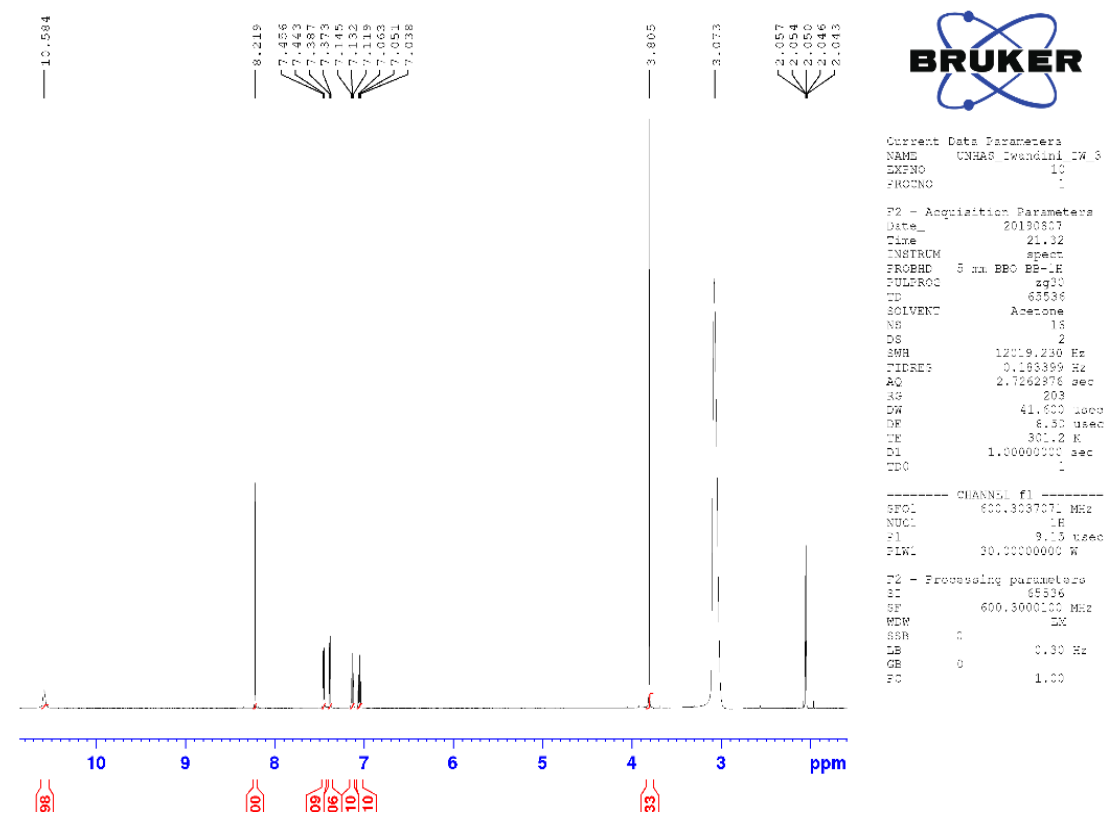

${ }^{1} \mathrm{H}$ NMR spectra of Compound $\mathbf{1}$ 


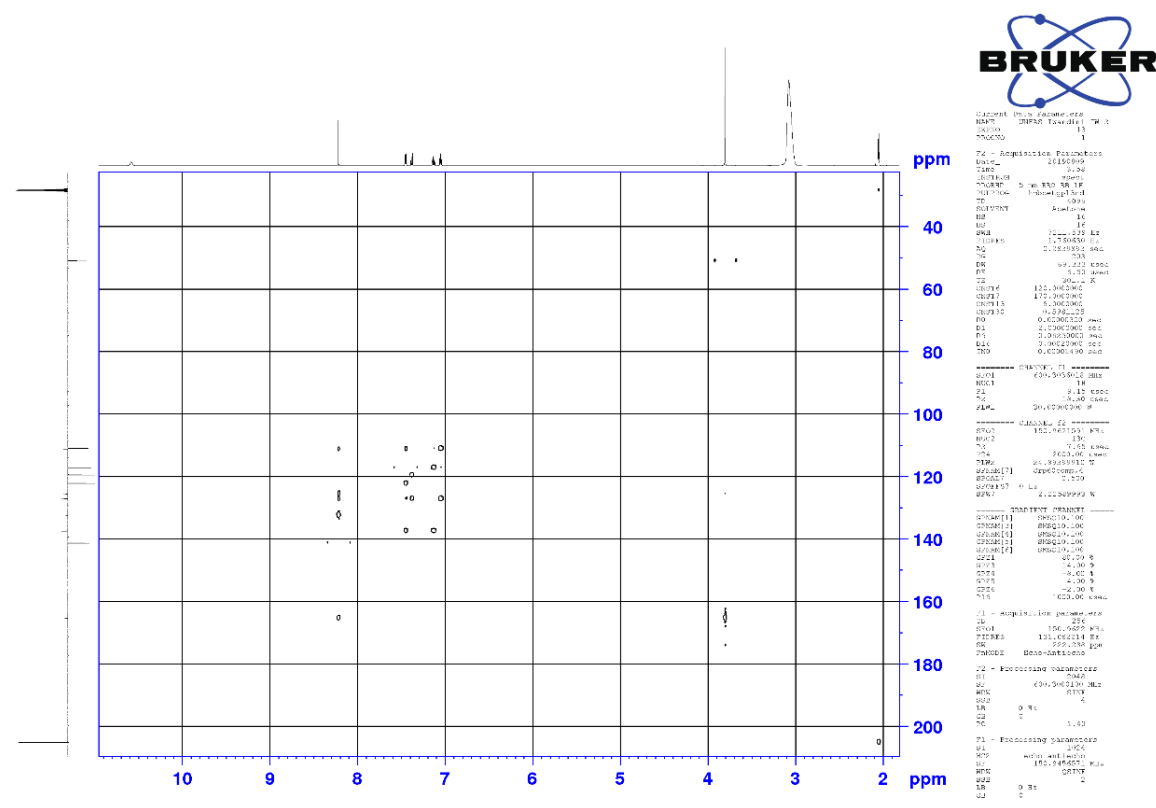

HMBC spectra of Compound 1
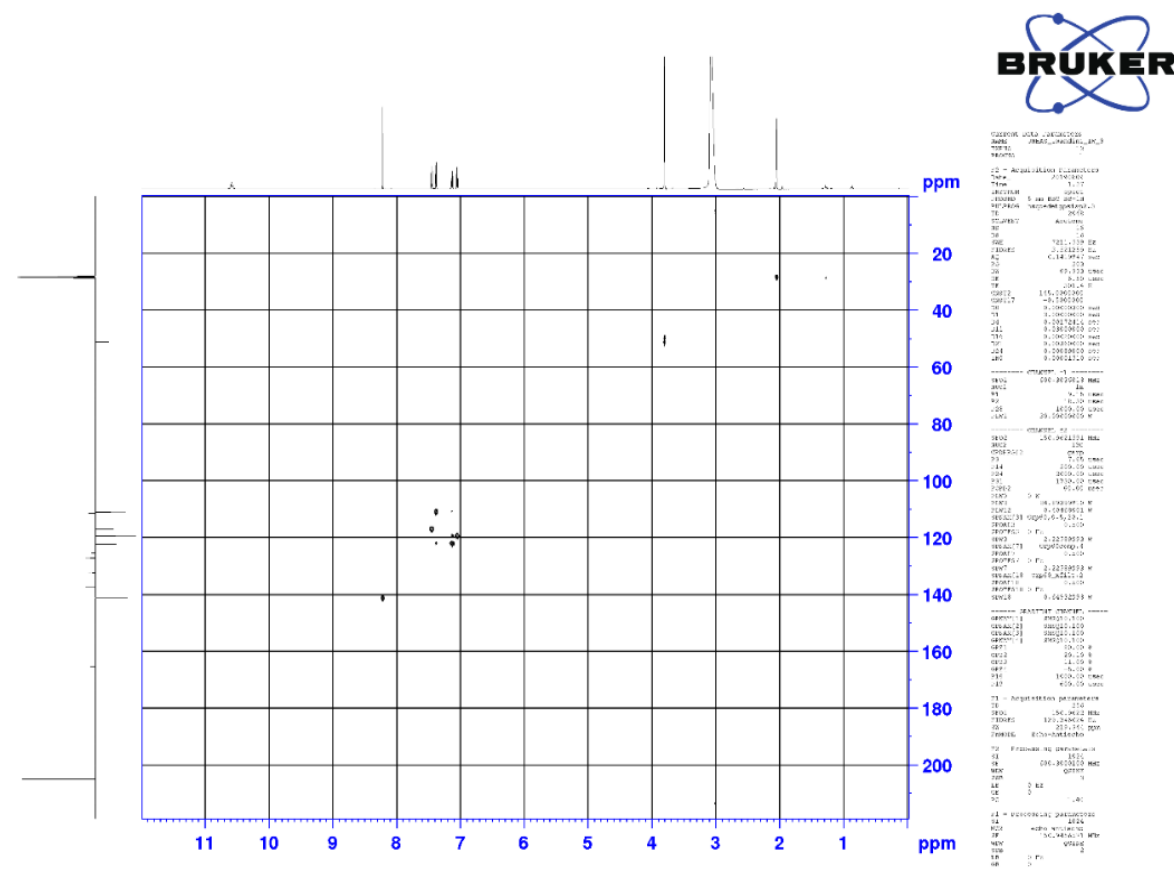

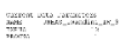

and

……

(1)

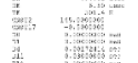

(1)

and

政,

나의

int

ind

$=$

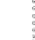

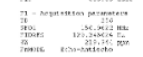

and

HMQC spectra of Compound $\mathbf{1}$ 

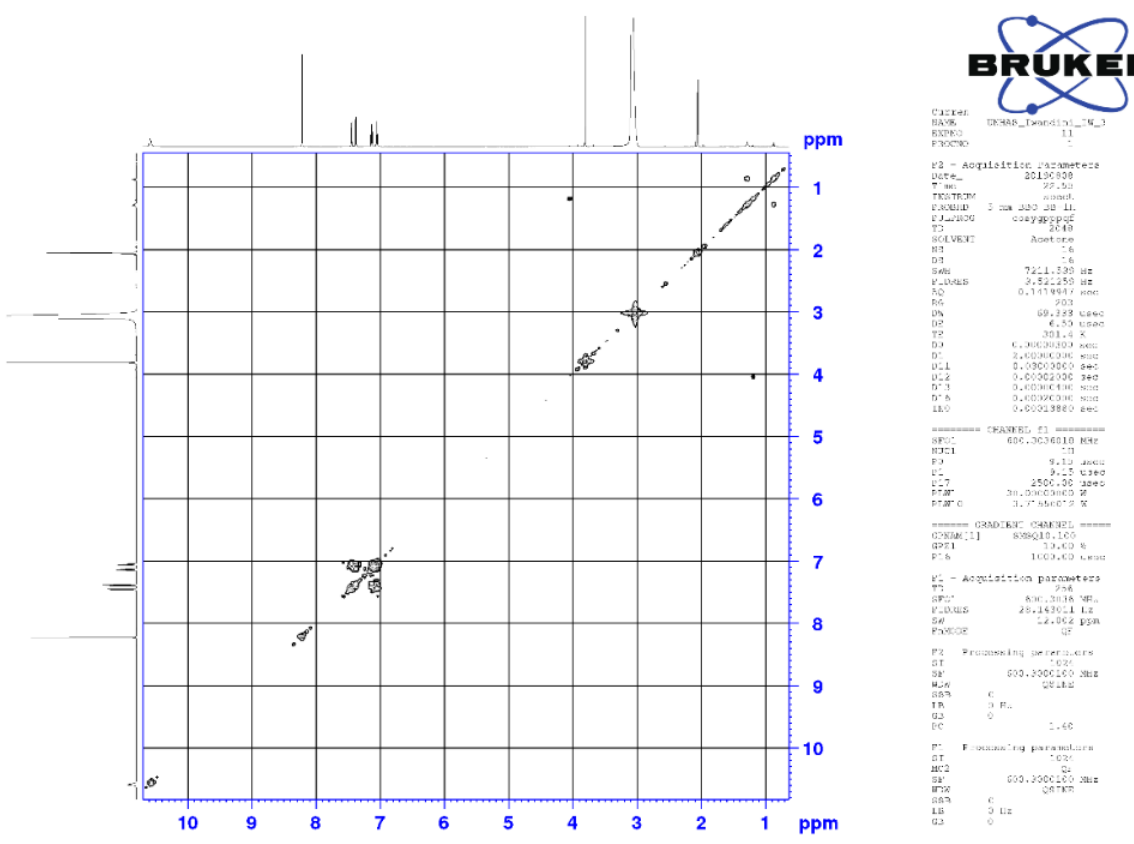

COSY spectra of Compound $\mathbf{1}$

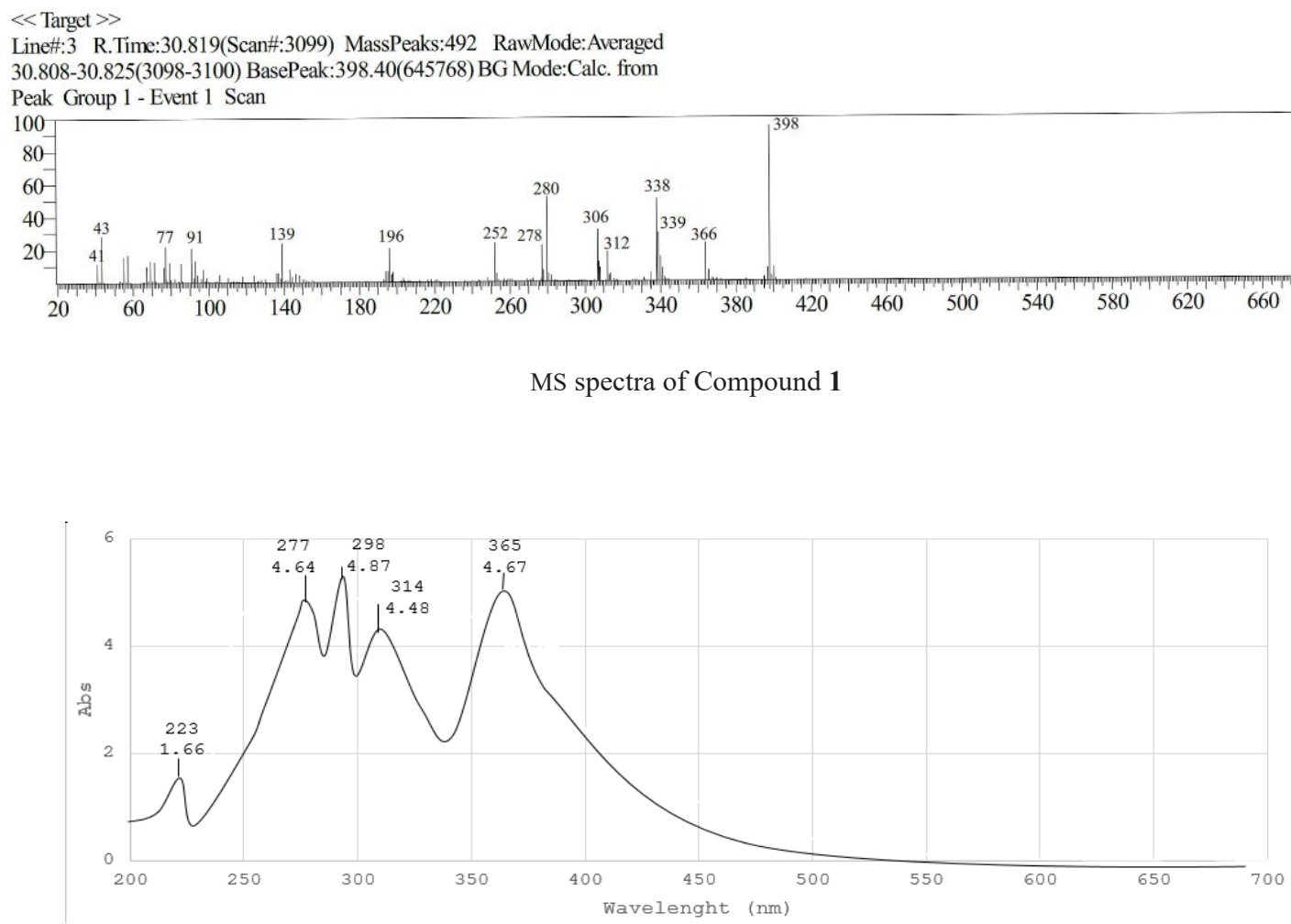

UV spectra of Compound $\mathbf{1}$ 

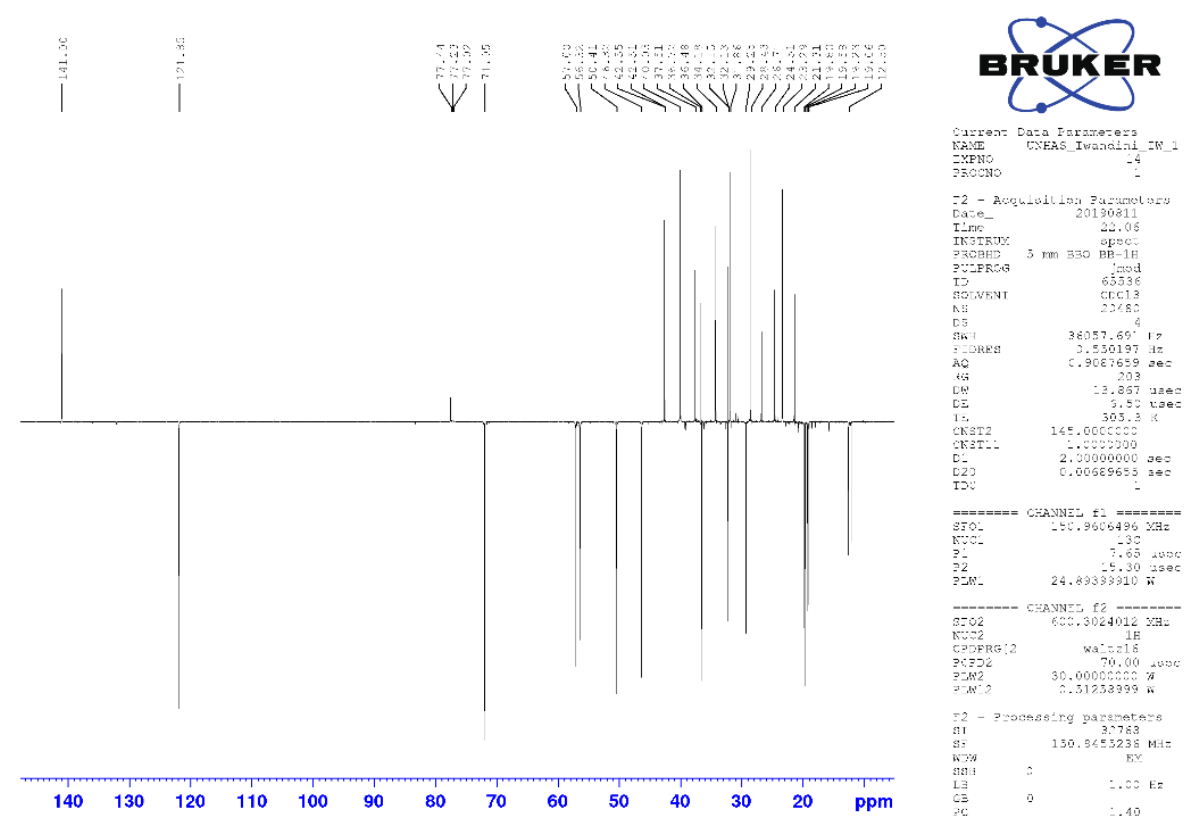

${ }^{13} \mathrm{C}$ NMR apt spectra of Compound 2
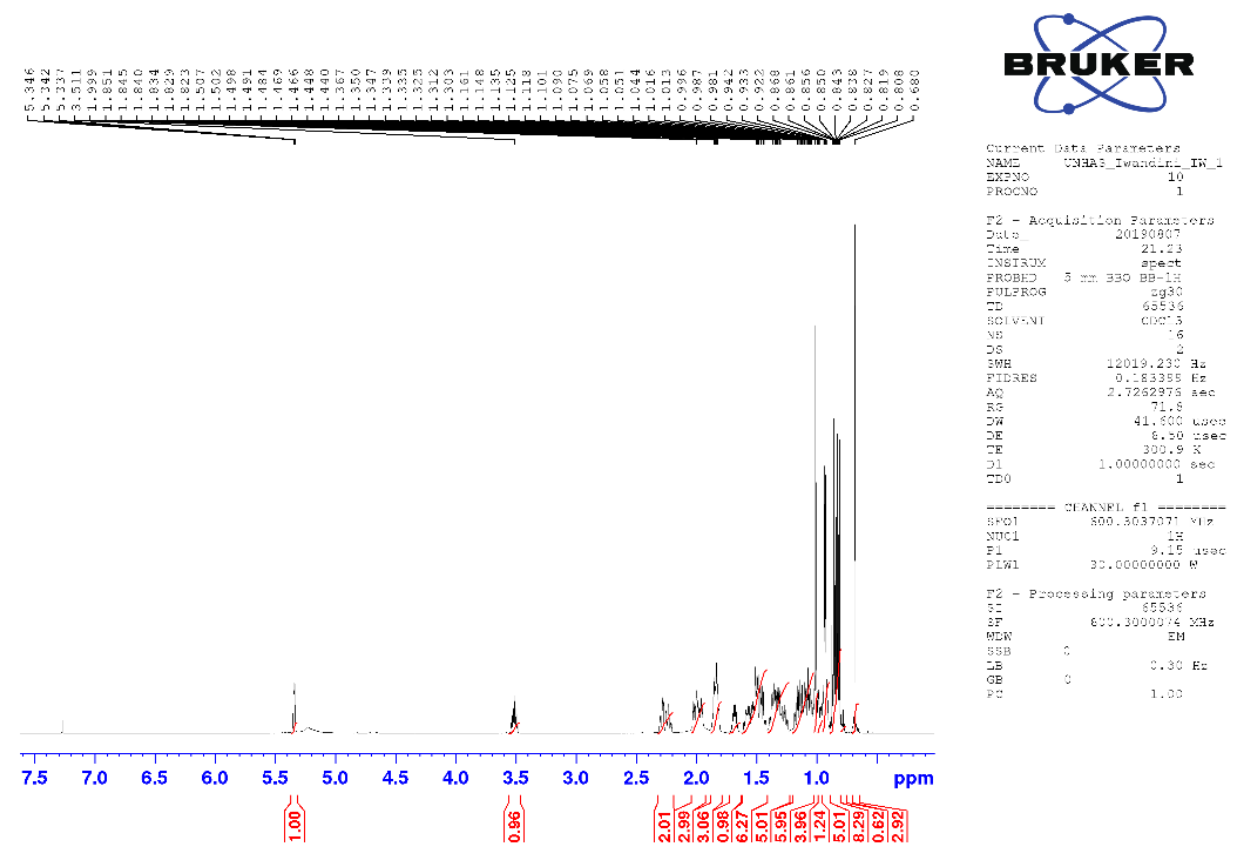

${ }^{1}$ H NMR spectra of Compound 2 
$<$ Target $>>$

Line\#:2 R.Time:28.533(Scan\#:2825) MassPeaks:506

RawMode:Averaged 28.525-28.542(2824-2826) BasePeak:414.25(18669)

BG Mode:Calc. from Peak Group 1 - Event 1 Scan

100

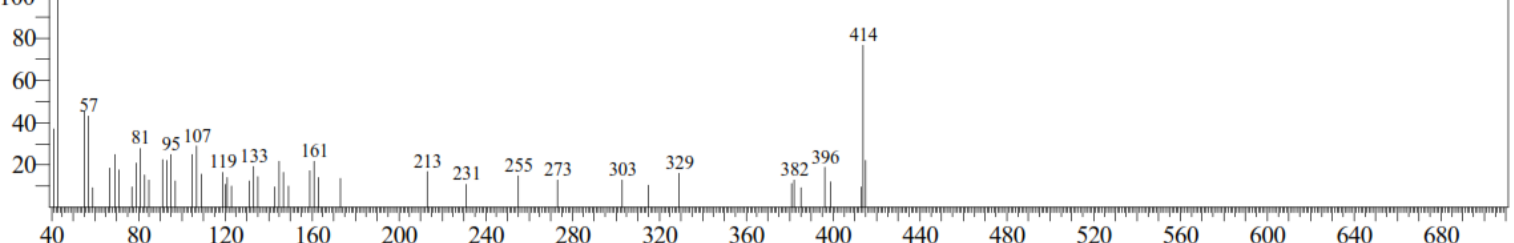

MS spectra of Compound 2 